Середа Валентина Іванівна кандидат економічних наук, доцент, Київський національний університет імені тараса Шевченка, м. Київ, 03022, вул Васильківська, 90-а, тел.: (044) 257-92-91, e-mail: valentinasereda10@gmail.com; https://orcid.org/0000-0002-7697-4704

Баліоз Діана Борисівна провідний економіст, Національний банк України, відділ аналізу міжнародної економіки, Департамент монетарної політики та економічного аналізу, вул. Інститутська, 9, м. Київ, 01601, e-mail: diana.balioz@gmail.com.; https://orcid.org/0000-0002-6239-1372

\title{
ВПЛИВ ДІЯЛЬНОСТІ ЄБРР НА ЕКОНОМІЧНИЙ РОЗВИТОК УКРАЇНИ
}

Анотація. У статті розглянуто особливості співпраці ЄБРР за країнами Східної Свропи та Кавказу, визначено тенденції щодо залучення коштів СБРР в ці країни. Визначено, що Україна $є$ найбільшим партнером ЄБРР в своїй групі.

Охарактеризовано співпрацю України та ЄБРР, розглянута динаміка виділення кредитних ресурсів на проекти в Україні, виявлено основні галузі діяльності та напрямки співпраці: інфраструктура, енергетика, промисловість, торгівля та сільське господарство, фінансові інституції. Зростає частка надходжень кредитних ресурсів у державний сектор.

Доведено і обгрунтовано за допомогою економетричного моделювання вплив інвестицій ЄБРР на основні макроекономічні показники економіки України: фінансування проектів в ключових сферах в найбільшій мірі вплинуло на ВВП на душу населення, кінцеву енергоємність валового внутрішнього продукту, валову додану вартість, індекс сприйняття корупції та позицією в рейтингу Doing Business.

Проаналізовано стратегію співпраці України ЄБРР на 2018-2023 рр. для стабілізації економічного розвитку. Визначено, що поставлена мета та пріоритетні напрямки співпраці передбачають, в першу чергу, зміцнення інституційного середовища: сприяння приватизації державного сектору, підвищення конкурентоспроможності, сприяння верховенству права, посилення енергетичної безпеки та енергоефективності.

Проведено SWOT-аналіз співпраці України та СБРP та визначено основні задачі для підвищення ефективності реалізації проектів для розвитку економіки України. Це може бути також використано для подальших досліджень у сфері 
міжнародної інвестиційної діяльності України, поліпшення інвестиційного клімату та співпраці з фінансовими інституціями.

Результати проведеного дослідження можуть використовуватися під час вивчення особливостей та результативності співпраці країн 3 іншими міжнародними фінансовими організаціями.

Ключові слова: економічний розвиток, ЄБРР, каузальність, міжнародна фінансова організація, міжнародні інвестиції, стратегія економічного розвитку.

Sereda Valentyna Svanivna Candidate of Economic Sciences $(\mathrm{PhD}$ in Economics), Associate Professor, Taras Shevchenko National University of Kyiv, Department of International Economics and Marketing, Vasylkivska St., 90-a, Kyiv, 03022, tel: (044) 257-92-91, e-mail: valentinasereda10@gmail.com, https://orcid.org/0000-0002-7697-4704

Balioz Diana Borysivna Lead economist, National bank of Ukraine, International Economy Analysis Unit, Monetary Policy and Economic Analysis Department, Kyiv, 01601, Instytutska St., 9, e-mail: diana.balioz@ gmail.com, https://orcid.org/0000-00026239-1372

\section{THE IMPACT OF THE EBRD'S ACTIVITIES ON UKRAINE'S ECONOMIC DEVELOPMENT}

Abstracts. This article discusses the peculiarities of EBRD's cooperation with the Eastern Europe and Caucasus, defines tendencies of attracting EBRD funds to these countries. It is identified that Ukraine is the biggest EBRD's partner in its region.

This article outlines the cooperation between Ukraine and the EBRD, the dynamics of loans allocation to the projects in Ukraine, and defines main sectors for cooperation: infrastructure, energy, industries, trade and agriculture, financial institutions. The share of investments into public sector tends to grow.

The impact of the EBRD investments on Ukraine's main macroeconomic variables is estimated using econometric modelling: the main influence is on GDP per capita, energy intensity of GDP, GVA, Corruption perception index, and the Doing Business ranking.

The EBRD's Strategy for Ukraine for 2018-2023 is analyzed. The aim and priority areas of cooperation mainly include institutional environment strengthening, i.e. promoting public sector privatization, increasing competitiveness, promoting the rule of law, enhancing energy security and energy efficiency. The SWOT-analysis of the collaboration between Ukraine and the EBRD detects main goals for enhancing efficacy of projects. This can also be utilized for further research on international 
investment activities of Ukraine, for the investment climate improvement, and cooperation with financial organizations.

The results of this research can be applied to studies of peculiarities of countries' cooperation with international financial organizations, in particular for the case of collaboration between Eastern Europe and Caucasus with the EBRD.

Keywords: economic development, EBRD, causality, international financial organization, international investment, economic development strategy.

Постановка проблеми. Питання економічного розвитку країн Східної Свропи та України зокрема $є$ особливо актуальними на сучасному етапі. Міжнародні фінансові інституції відіграють вирішальну роль у стимулюванні змін у цих країнах, впливають на перебіг процесів реформування i трансформацій, мають позитивний вплив на економічний розвиток загалом.

Особливу роль у соціально-економічному розвитку України відіграє Європейський банк реконструкції i розвитку (СБРР), який $\epsilon$ найбільшим інституційним інвестором для нашої держави.

Європейський банк реконструкції і розвитку (СБРР) був заснований з метою допомогти у побудові нової ери після періоду Холодної війни у Центральній i Східній Європі. 3 тих пір він відіграє значну роль і отримав унікальний досвід у стимулюванні змін у даному регіоні та за його межами. Метою діяльності ЄБРР $\epsilon$ досягнення переходу країн до ринкової економіки та сприяння приватній i підприємницькій ініціативі.

Як відомо, ЄБРР поєднує риси міждержавної організації, інвестиційного банку та комерційного банку. Основними елементами механізму фінансування СБРР є кредитування, інвестиції у власний капітал підприємств, надання гарантій для стимулювання торгівлі, а також спільне фінансування з іншими фінансовими інституціями, надання технічної допомоги і консультування. Тому визначення результативності впливу проектів ЕБРР на різні сфери економіки України має надзвичайно важливе значення для формування стратегічних напрямків співпраці. Проте українськими дослідниками приділяється недостатньо уваги цьому аспекту.

Аналіз останніх досліджень і публікацій. Теоретичні та практичні аспекти співробітництва 3 міжнародними кредитно-фінансовими організаціями розглядалися в працях відомих вітчизняних науковців Б Губського, А. Кредисова, В. Новицького, А. Поручника, С. Сокаленка, А. Філіпенка. Але серед наукових публікацій в Україні переважають роботи, що виявляють динаміку інвестицій ЕБРР в Україну та стан фінансування проектів [1]. В окремих статтях аналізуються позитивні та негативні аспекти цієї співпраці [2].

Іноземні науковці розглядають ці питання ширше. Так, Hagiu A., Bărbulescu M. 
та Voicu D., аналізуючи діяльність ЄБРР в Румунії, пропонують стратегічні пріоритети на період 2020-25 рр.: сприяння інвестиціям у стійку інфраструктуру (sustainable infrastructure) i регіональний розвиток, підтримку продуктивності шляхом розширення корпоративних інновацій та модернізації навичок, розширення фінансового посередництва i ринків капіталу [3]. Kosutic A. розглядає роль ЄБРР в контексті розвитку фінансового сектору Сербії: інвестиції СБРР поліпшили якість і показники кредитування, забезпечили стабільність фінансових ринків і попередили повний колапс фінансового сектору в період кризи [4].

Цікавим є дослідження Natalia Kryg, де вплив факторів на нефінансовий успіх інвестицій СБРР (демонстрація нових методів фінансування, розширення конкурентних ринків) на основі фактичного аналізу розглядається в прогнозному періоді. Результати дослідження показали, що ймовірність успіху вища для великих i рамкових проектів, але $\epsilon$ меншою для проектів 3 державними підприємствами, оскільки державна власність значно сповільнює виконання проекту [5].

Аналіз результатів співпраці України з СБРР потребує ширшого підходу у зв’язку із специфікою діяльності даної організації та в умовах зростаючої необхідності залучення додаткових коштів у різні сектори економіки України.

МЕТА СТАТТІ - УЗАГАЛЬНЕННЯ НАПРЯМКІВ ТА ОСОБЛИВОСТІ СПІВПРАЦІ УКРАЇНИ 3 ЄБРР, ВИЯВЛЕННЯ ВПЛИВУ ІНВЕСТИЦІЙ ЄБРР НА ЕКОНОМІЧНИЙ РОЗВИТОК УКРАЇНИ ТА НАДАННЯ ПРАКТИЧНИХ РЕКОМЕНДАЦЙ ЩОДО ВИЗНАЧЕННЯ ЗАДАЧ ДЛЯ РЕАЛІЗАЦЇ СТРАТЕГІЇ ВИКОРИСТАННЯ КОШТІВ ЄБРР В УКРАЇНІ.

Виклад основного матеріалу. СБРР у межах своєї діяльності і співпраці 3 країнами виділяє сім основних регіонів: п'ять регіональних груп країн, а також країни Туреччина і Росія виділені окремо. До регіону Східної Європи і Кавказу за класифікацією ЄБРР належать такі країни: Вірменія, Азербайджан, Білорусь, Грузія, Молдова, Україна. Цікаво, що такий розподіл країн цього регіону співпадає із так званим «Східним партнерством», що $\epsilon$ однією із важливих політичних та економічних стратегій розвитку цих країн. Після розпаду Радянського Союзу та соціалістичного блоку більшість постсоціалістичних країн опинились у схожих умовах, але шлях переходу від командно-адміністративної системи до ринкової економіки у кожної був різний.

Групування країн за методологією ЄБРР відображає їхнє об'єднання за історичними передумовами, спільними рисами у процесі впровадження реформ та їхньої результативності. Можна виділити загальні спільні риси, притаманні економічному розвитку та реформам країн Східної Свропи та Кавказу:

1) реформи тут проходили важче, ніж, наприклад, у країнах Центрально- 
2) Східної Свропи і країнах Балтії, і позитивний ефект вони дали пізніше. Практично, лише починаючи 32000 р. почалося деяке наростання темпів економічного розвитку. Зникали окремі галузі, що було пов'язано із залежністю від вибудованої виробничо-коопераційної системи СРСР, коли промисловість і виробництво у кожній з країн були продовженням циклу, розпочатого в інших республіках;

3) економічні реформи в пострадянських державах спрямовувалися переважно на швидку трансформацію відносин власності. У таких країнах регіону Східної Європи та Кавказу, як Білорусь і Азербайджан, в економіці досі домінує державний сектор [6];

4) ВВП знизився в середньому на 20-30\%, безробіття з практично нульової позначки зросло до 10-20\%, реальна заробітна плата скоротилася. Спостерігалося падіння обсягів виробництва у всіх секторах економіки, зубожіння більшості населення, майнове розшарування. Приватизація не призвела до структурної перебудови економіки й не створила широкого класу власників;

5) багато в чому стихійний процес лібералізації без чіткої програми разом із високим рівнем корумпованості викликав серйозну за масштабами і наслідками кризу в економіці, соціальну напруженість, падіння життєвого рівня значної частини населення [7].

Основні тенденції щодо залучення коштів ЄБРР країнами Східної Європи та Кавказу:

- на регіон Східної Свропи та Кавказу щорічно припадає близько п’ята частина усіх коштів, виділених СБРР;

- у регіоні найбільшим реципієнтом традиційно є Україна;

- найбільша кількість проектів у регіоні здійснюються у секторах енергетики та інфраструктури, на розвиток фінансового сектору припадає незначний відсоток проектів;

- частки проектів у приватному секторі $\epsilon$ різними, однак загалом усі вони вибиваються із загального співвідношення для ЄБРР (традиційним співвідношенням $€$ як мінімум $60 \%$ у приватному секторі, решта - державний сектор; у регіоні ж Східної Європи та Кавказу ЄБРР здійснює значні інвестиції у державний сектор);

- спільними проблемами в залученні коштів СБРР країнами регіону $\epsilon$ відсутність ефективного менеджменту в країнах, регуляторне обтяження комунікаційного процесу 3 Банком, низька культура відповідальності, нерозвиненість інститутів прозорості і приватної власності;

- окрім прямого залучення інвестицій СБРР, країни Східної Свропи та Кавказу також одержують кошти від ініціатив та проектів СБРР спільно 3 іншими міжнародними організаціями та об’єднаннями [8]. 
Основні макроекономічні показники цих країн до останнього часу (до кризи, пов’язаної з Covid-19) засвідчували помірний розвиток економік країн Східної Європи та Кавказу, демонстрували позитивну динаміку та мали оптимістичні прогнози.

Україна є важливим регіоном діяльності СБРР. Усього за період діяльності 1992-06.2021 pр. було затверджено 499 проектів, що є значно більшою кількістю порівняно з усіма іншими країнами регіону Східної Свропи та Кавказу. Причому кількість проектів в Україні тільки за період 2018-06.2021 збільшилась на 25\%. Загальні кумулятивні інвестиції ЄБРР в Україну станом на 01.06.2021 p. становили 14,8 млрд. євро. Тільки за останні три роки приріст фінансування склав 23\%. Вісім проектів загальним обсягом позик 1679,3 млн євро (на 01.06.2021) знаходиться на стадії реалізації в державному секторі [9]. Поточний портфель проектів станом на 01.08.2021 р. складає 4,009 млрд. євро [10].

ЄБРР є найбільшим інституційним інвестором в Україні: на нашу країну припадає найбільша частка всіх інвестицій в групі Східна Європа та Кавказ близько $42 \%$ у 2020 р. (рис.1). Україна є третьою за обсягами інвестицій країною операцій ЄБРР (після Туреччини і Сгипту) [11].

За останні 4 роки дещо змінилась галузева структура проектів: збільшилась частка проектів в інфраструктуру (з $34 \%$ до 56\%), в сектор промисловості, торгівлі та сільського господарства (з 27\% до 34\%), дещо зменшилась - у фінансовий сектор (з 11\% до 10\%) [12].

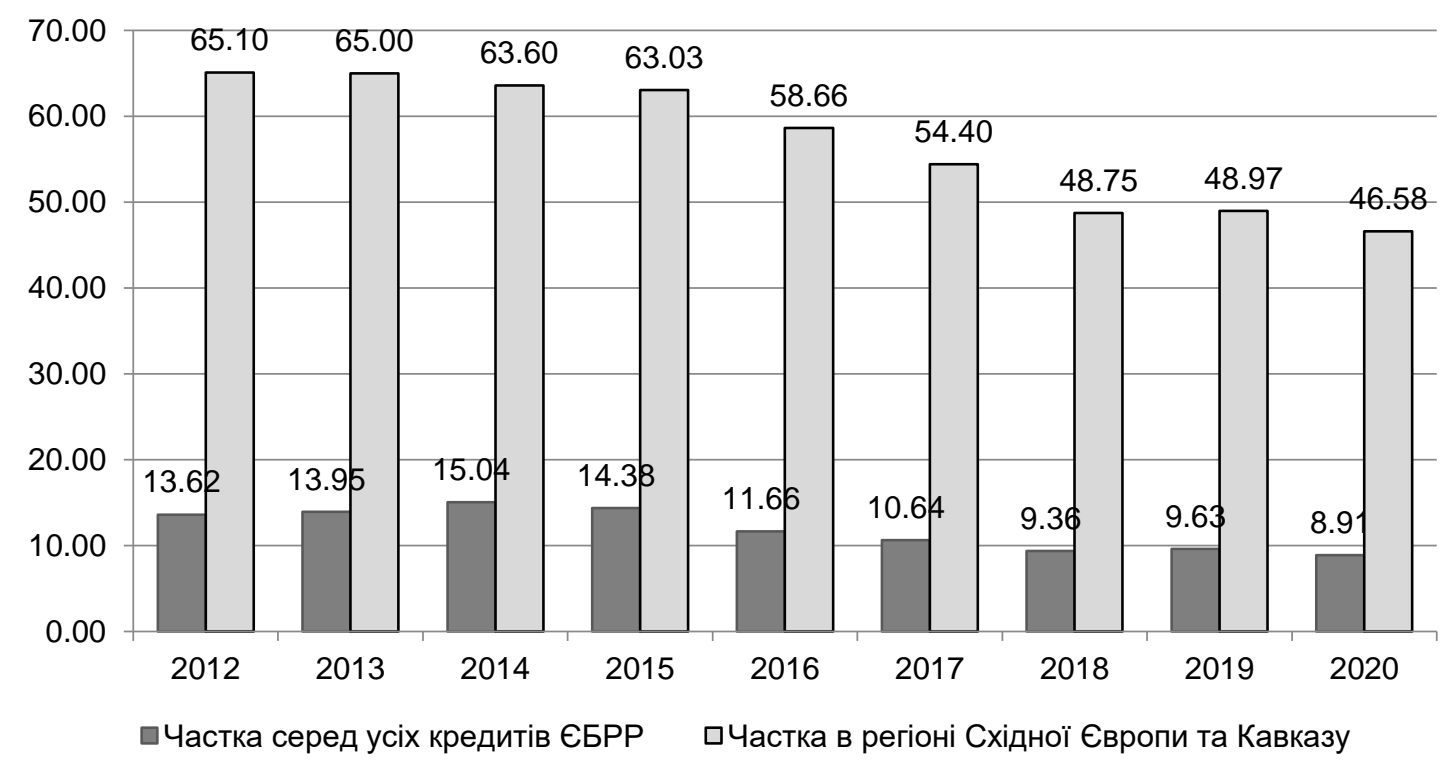

Puc. 1. Частка одержаних Україною кредитних ресурсів СБРР серед усіх регіонів діяльності та в регіоні Східної Свропи та Кавказу

Джерело: складено на основі [11].

3 усіх погоджених для інвестування проектів СБРР в Україні сьогодні 45\% припадає на приватний сектор (для порівняння у 2014 році цей показник 
перевищував 50\% для приватного сектору, а понад 5 років тому - був більшим за 60\%). Тобто останніми роками існує тенденція до збільшення кількості проектів у державному секторі. На інвестиції СБРР у власний (акціонерний) капітал підприємств припадає 8\% усього портфелю діяльності Банку в Україні.

Щорічна динаміка обсягів інвестицій СБРР в Україну та кількості здійснених проектів наведено на рис. 2.

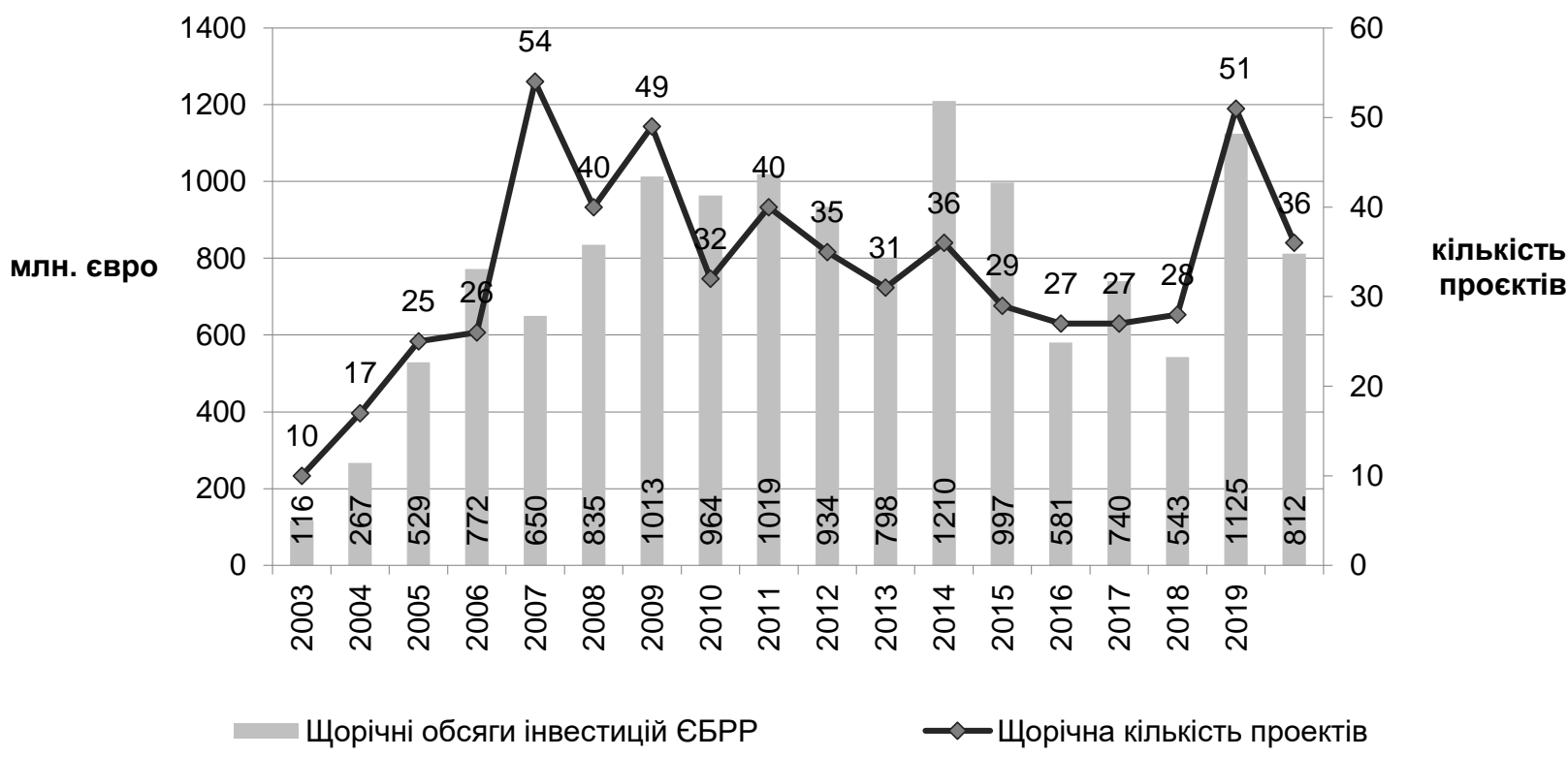

Puс. 2. Щорічні показники інвестицій СБРР в Україну

Джерело: складено на основі [12].

Як бачимо, за останні 18 років загальні щорічні обсяги інвестицій СБРР в Україну зросли більше, ніж у 10 разів, якщо порівнювати 3 піковими роками (2014, 2019). Найбільший притік припав на 2014 р. що пов’язано з підтримкою СБРР України у складній макроекономічній та геополітичній ситуації військового конфлікту та бажанням здійснити структурні і галузеві реформи, підтримати малий бізнес тощо.

Окрема ініціатива присвячена питанню аварії в Чорнобилі: уже закінчено будівництво гігантської покривної споруди (ковпака) над реактором (проект «Укриття»). Зараз СБРР управляє Рахунком ядерної безпеки (Nuclear Safety Account), 3 якого фінансуються два додаткові об’єкти інфраструктури, що стосуються ліквідації наслідків катастрофи: 1) тимчасове сховище відпрацьованого палива 2; вартість об'єкта перевищує 400 мільйонів євро; 2) завод з переробки рідких радіоактивних відходів. На чорнобильські проекти під управлінням СБРР було отримано понад 2 мільярди євро від 45 країн-донорів. СБРР виділив 715 мільйонів євро 3 власних ресурсів на підтримку роботи 3 перетворення Чорнобиля в екологічно безпечний об'єкт [13].

Аналіз економічної ситуації аналітиками ЄБРР в Україні в 2020-21 pp. 
показав, що економіка країни повертається до зростання, але стримуючим фактором виступають структурні недоліки. В 2020 р. ВВП знизився на 4\% внаслідок скорочення зовнішнього попиту та обмежень внутрішнього попиту, пов'язаних iз Covid-19. В цих умовах покращення макрофінансового управління виявилось тим чинником, який забезпечив підтримку макроекономічної стабільності [14].

Важливим є виявлення комплексного впливу інвестицій СБРР на розвиток економічної системи України через взаємозв'язок 3 осиновими макроекономічними та рейтинговими показниками: індекс сприйняття корупції, Індекс легкості ведення бізнесу, енергоємність кінцевого споживання, валова додана вартість, ВВП на душу населення, Індекс глобальної конкурентоспроможності економіки, зайнятість населення, середня заробітна плата, інфляція та ін.

Для цього спочатку було побудовано кореляційну матрицю для показників: інвестиції ЄБРР в Україну (EBRDCUMUL; для таблиці та наступних моделей цей показник розраховано кумулятивним методом для більшої наочності результатів), Індекс сприйняття корупції (CORRUP), Індекс легкості ведення бізнесу (DBusiness), енергоємність кінцевого споживання (ENERGY), валова додана вартість (GVA), ВВП на душу населення (GDPCAP), Індекс глобальної конкурентоспроможності економік (GLOBCOMP), зайнятість населення (\%) (LEMP). Статистичні дані для розрахунків зібрано за останні 15 років. Також було досліджено кореляцію з обсягами інвестицій ЄБРР i для деяких інших показників (середня заробітна плата, інфляція, кількість непрацюючих кредитів NPL тощо), однак у зв'язку із відсутністю стійких кореляційних зв'язків між ними та коштами СБРР їхні результати не було винесено в табл. 1.

3 кореляційної матриці видно, що показник залучених Україною коштів ЄБРР має сильний обернений зв'язок з місцем України в рейтингу Світового Банку Doing Business (оберненість взаємозв'язку є логічною: чим більші обсяги інвестицій СБРР, тим менше значення місця в рейтингу, тобто тим вище підняття в цьому рейтингу). Так само інвестиції ЄБРР впливають на зменшення енергоємності кінцевого споживання ВВП, тобто сприяють збільшенню енергоефективності економіки, що пояснюється участю України в програмах та проектах ЄБРР в енергетичному секторі. Прямий сильний зв'язок спостерігається між залученими коштами СБРР та обсягами валової доданої вартості. Середня кореляція має місце між інвестиціями СБРР та ВВП на душу населення, індексом глобальної конкурентоспроможності та сприйняттям корупції. Середній, але обернений зв'язок притаманний для коштів СБРР та рівня зайнятості населення, що є нелогічним і може бути інтерпретовано випадковою кореляцією підібраних даних; найімовірніше на зайнятість та безробіття впливають зовсім інші фактори, 
ніж фінансування СБРР.

Таблиия 1.

Кореляційна матриця інвестицій ЄБРР та показників економічного і соціального розвитку України

\begin{tabular}{|l|l|l|l|l|l|l|l|l|}
\hline & CORRUP & DBusiness & $\begin{array}{l}\text { EBRD } \\
\text { CUMUL }\end{array}$ & ENERGY & GVA & $\begin{array}{l}\text { GDP } \\
\text { CAP }\end{array}$ & $\begin{array}{l}\text { GLOB } \\
\text { COMP }\end{array}$ & LEMP \\
\hline CORRUP & $\mathbf{1 . 0 0 0 0}$ & -0.5640 & 0.5004 & -0.6815 & 0.8396 & 0.1494 & 0.0368 & -0.5456 \\
\hline DBusiness & -0.5639 & $\mathbf{1 . 0 0 0 0}$ & -0.9104 & 0.9832 & -0.8842 & -0.2082 & 0.1645 & 0.7051 \\
\hline $\begin{array}{l}\text { EBRD } \\
\text { CUMUL }\end{array}$ & 0.5004 & -0.9104 & $\mathbf{1 . 0 0 0 0}$ & -0.8982 & 0.7776 & 0.5610 & -0.5107 & -0.4378 \\
\hline ENERGY & -0.6815 & 0.9832 & -0.8982 & $\mathbf{1 . 0 0 0 0}$ & -0.9319 & -0.1923 & 0.1806 & 0.7064 \\
\hline GVA & 0.8396 & -0.8842 & 0.7776 & -0.9319 & $\mathbf{1 . 0 0 0 0}$ & 0.1218 & -0.0018 & -0.6293 \\
\hline GDPCAP & 0.1494 & -0.2082 & 0.5611 & -0.1924 & 0.1218 & $\mathbf{1 . 0 0 0 0}$ & -0.7728 & 0.1616 \\
\hline $\begin{array}{l}\text { GLOB } \\
\text { COMP }\end{array}$ & 0.0368 & 0.1645 & -0.5107 & 0.1806 & -0.0018 & -0.7728 & $\mathbf{1 . 0 0 0 0}$ & -0.2417 \\
\hline LEMP & -0.5456 & 0.7051 & -0.4378 & 0.7064 & -0.6293 & 0.1616 & -0.2417 & $\mathbf{1 . 0 0 0 0}$ \\
\hline
\end{tabular}

За допомогою методу найменших квадратів було побудовано ряд регресійних моделей. Після перевірки моделей на адекватність та параметрів на статистичну значущість, було відібрано такі моделі:

$$
\text { DoingBusiness }=a * E B R D C U M U L+b * W A G E+e
$$

де DoingBusiness - місце України в рейтингу легкості ведення бізнесу, EBRDCUMUL - накопичені обсяги коштів СБРP, WAGE - середня заробітна плата, е - випадковий (стохастичний) компонент. Після побудови регресії кінцеве рівняння даної багатофакторної моделі має вигляд:

$$
\text { DoingBusiness }=-0.0064 * W A G E-0.0118 * E B R D C U M U L+218.43
$$

3 моделі видно, що кошти ЄБРР дійсно сприяють підняттю України в рейтингу DoingBusiness, однак значну роль відіграють також інші фактори (ПII, глобальна конкурентоспроможність, податкове законодавство), що приховані у стохастичному компоненті (найбільший коефіцієнт - 218.43) i можуть бути предметом окремого дослідження. Коефіцієнт детермінації для даної моделі становить 0,85 , що свідчить про адекватність і правильність побудованої залежності.

Вплив коштів СБРР та інших факторів на енергоємність кінцевого споживання енергії за останні 15 років було підтверджено за допомогою залежності [67]:

$$
\begin{aligned}
& \text { ENERGY }=-7.67 * 10^{-6} \text { EBRDCUMUL }+5.97 * 10^{-7} \text { FDI }+ \\
& 0.0014 \text { CORRUP }+0.1732
\end{aligned}
$$


де ENERGY - енергоємність кінцевого споживання (в тонах нафтового еквіваленту на $\$ 1000$ BВП), FDI - притік прямих іноземних інвестицій. Коефіцієнт детермінації 0,96 - модель адекватна; усі фактори, крім індексу сприйняття корупції, є абсолютно статистично значущими. Розроблена модель також підтверджує позитивний вплив СБРР на підвищення енергоефективності споживання в Україні.

Більш комплексну картину впливу коштів СБРР на економіку України в цілому демонструють розроблені нелінійні моделі виробничих функцій: Кобба Дугласа для ВВП (GDP) (формула (4)), Кобба - Дугласа для валової доданої вартості (5) - для обох як фактор капіталу взято інвестиції СБРР в Україну, як фактор праці - рівень зайнятості населення, А - коефіцієнт розмірності (масштабний множник); а також найбільш комплексна модель, розроблена нами на основі функцій Кобба - Дугласа та Солоу (6):

$$
\begin{gathered}
G D P=A * E B R D C U M U L^{a} * L E M P^{b}=4.46 * E B R D C U M U L^{1.05} * L E M P^{540.85} \\
G V A=A * E B R D C U M U L^{a} * L E M P^{b}=1.74 * E B R D C U M U L^{1.58} * \\
L E M P^{0.0003} \\
G D P=-14.2 * G D P(-1)^{1.28} * L E M P^{e^{\wedge} 13} *\left(\frac{F D I}{G D P}\right)^{0.79} *\left(\frac{E B R D}{G D P}\right)^{0.7} * \\
(\text { DBusiness })^{2.24} * \text { Reforms }^{505}
\end{gathered}
$$

де $G D P(-1)$ - лагова змінна ВВП (показує залежність зміни в наступному періоді від попереднього), Reforms - інтегральний показник успішності трансформаційних реформ, розраховується СБРР (бали, від 1 до 4). Коефіцієнт детермінації моделі (6) - найвищий, 0,98 ; усі змінні в усіх рівняннях статистично значущі.

За допомогою каузального тесту Грейнджера для ряду змінних (у тому числі з використанням прийомів логарифмування, лагових змінних задля лінеаризації моделей та перетворення нестаціонарних часових рядів у стаціонарні, чого вимагає тест на каузальність), було виявлено який саме показник викликає зміну іншого показника, і чи є такий зв'язок двостороннім (змінні взаємно впливають одна на одну), чи дія є однонаправленою [15]. Результати проведених тестів на каузальність за Грейнджером підсумовано за допомогою схеми (рис. 3), що свідчить про тісний зв'язок між інвестиційними проектами СБРР та показниками соціально-економічного розвитку України. 


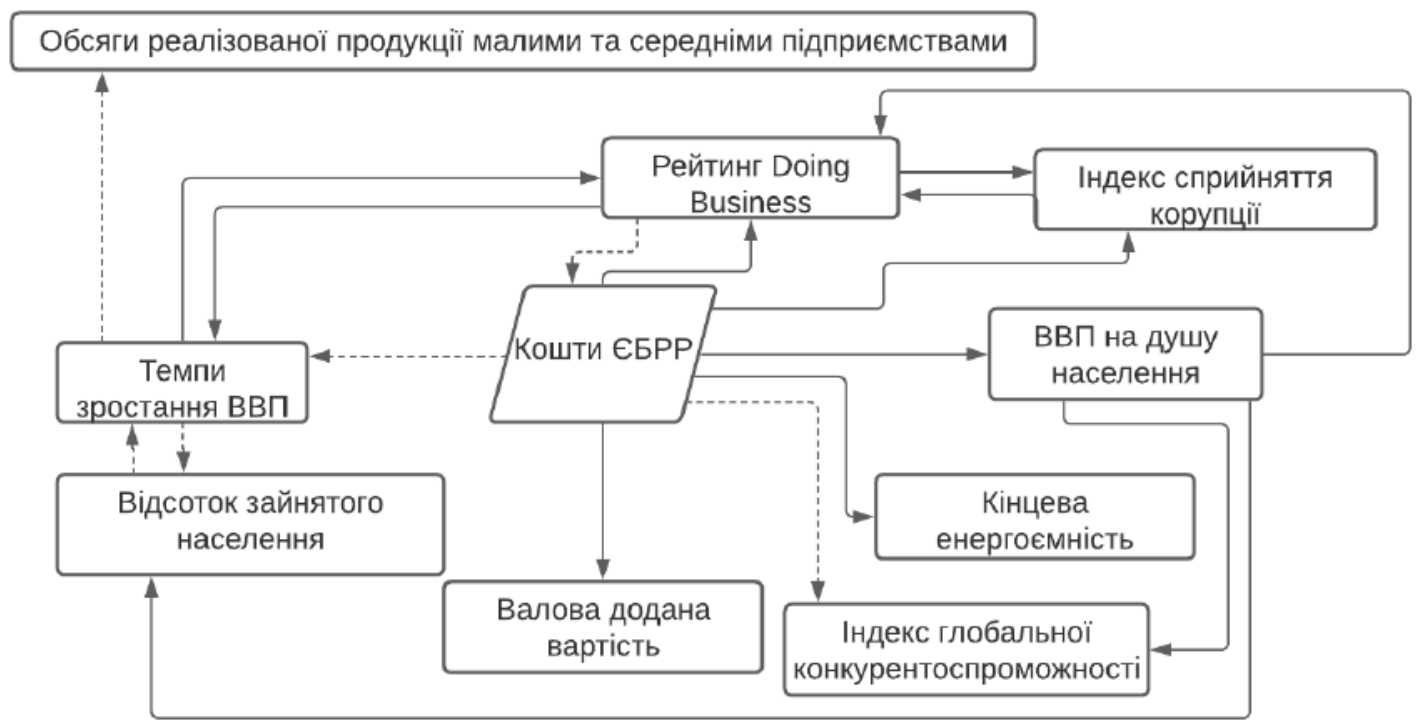

Pис. 3. Каузальність зв'язків між коштами СБРР та показниками соціально-економічного розвитку Украӥни

Отже, інвестиції ЄБРР в Україну здійснюють найбільший вплив на такі показники: ВВП на душу населення, кінцеву енергоємність валового внутрішнього продукту, валову додану вартість, індекс сприйняття корупції; взаємний двосторонній причинний зв'язок було виявлено між показниками коштів СБРР та позицією в рейтингу Doing Business (останній у свою чергу має сильний взаємний каузальний зв'язок із сприйняттям корупції). Більш слабкий, опосередкований причинно-наслідковий вплив інвестиції ЄБРР здійснюють на позицію України в індексі глобальної конкурентоспроможності, а також на темпи зростання ВВП, які у свою чергу, впливають на зміни в обсягах реалізованої продукції малими та середніми підприємствами. Таким чином, було виявлено та доведено значимість, міру та напрямки впливу коштів ЄБРР на стабілізацію економічного розвитку України.

В цьому контексті зрозуміло, що визначені ЕБРР сфери пріоритетного фінансування та зміст проектів, що реалізуються, відіграють вирішальну роль у стабілізації економічного розвитку України.

Стратегія для співпраці України та ЕБРР 2018-2023 pp. (Ukrainian Country Strategy, 2018-2023) за мету ставить перетворення відновлення, що почалося, у стійке зростання, подолання проблем в сферах та інституційному середовищі, які визначені ЕБРР як найважливіші для сталої ринкової економіки конкурентоспроможність, ефективне управління, екологічність, інклюзивність, сталість та інтеграційні процеси, а також боротьба 3 корумпованою «старою» економічною системою та інтересами, які вона представляє [16, с.3].

Стратегічними пріоритетами на цей період визначено:

1) Сприяння приватизації та комерціалізації в державному секторі для підвищення конкурентоспроможності та сприяння ефективному управлінню. 
ЕБРР буде стимулювати участь приватного бізнесу у всіх секторах (включаючи підтримку МСП), подальшу комерціалізацію компаній державного сектору, впровадження сучасних систем закупівель в державному секторі та належного державного управління.

2) Сприяння верховенству права, конкуренції та рівним умовам конкуренції в приватному секторі шляхом підтримки компаній із найкращою практикою через заохочення конкуренції та підтримки зусиль щодо боротьбі з корупцією. Особлива увага буде приділятися підвищенню кваліфікації та працевлаштуванню представників знедолених груп.

3) Посилення енергетичної безпеки шляхом ефективного регулювання, лібералізації ринку, диверсифікації та збільшення виробництва, а також енергоефективність. Банк буде виділяти більше ресурсів для створення ринкової інфраструктури стійкої енергетики та покращення енергетичної бази, сприяти підвищенню ефективності використання ресурсів та просуванню поновлюваних джерел енергії.

4) Підвищення стійкості фінансової системи шляхом зміцнення банківського сектору i ринків капіталу та інших небанківських фінансів, сприяння урізноманітненню небанківських фінансових активів та їхнього використання.

5) Посилення інтеграції через сприяння торгівлі та інвестиціям, розширення інфраструктурних зв'язків та зближення зі стандартами ЄС. Цей напрямок передбачено розвивати шляхом інвестування в розвиток інфраструктури, що буде сприяти збільшенню торгових та інвестиційних потоків [14; 16, с.3].

Здійснений SWOT-аналіз інвестиційної співпраці України з ЄБРР наведений в табл. 2.

Табличя 2.

SWOT-аналіз співпраці України з ЄБРР

\begin{tabular}{|c|c|}
\hline Сильні сторони & Слабкі сторони \\
\hline $\begin{array}{ll}\text { • } & \text { Україна - важлива країна операцій СБРР } \\
\text { (третя за річним обсягом інвестицій); } \\
\text { • } \\
\text { Тенденція до збільшення диверсифікації } \\
\text { інвестиційного портфелю; } \\
\text { • Комплексний характер проектів; } \\
\text { Значна частка проектів у сфері розвитку } \\
\text { інфраструктури та енергетики, } \\
\text { • Активне громадянське суспільство } \\
\text { • Просування по шляху структурних } \\
\text { реформ }\end{array}$ & $\begin{array}{l}\text { • Внутрішні перепони в Україні: } \\
\text { недосконалий менеджмент, корупція, } \\
\text { нестабільність законодавства; } \\
\text { • Невелика частка (10\%) проектів СБРР у } \\
\text { фінансовому секторі } \\
\text { • Недостатня підтримка розвитку фінансового } \\
\text { сектору економіки; } \\
\text { • Проблеми інвестиційної інфраструктури в } \\
\text { Україні } \\
\text { • Зменшення частки проектів в приватному } \\
\text { секторі }\end{array}$ \\
\hline
\end{tabular}




\begin{tabular}{|c|c|}
\hline Можливості & Загрози \\
\hline 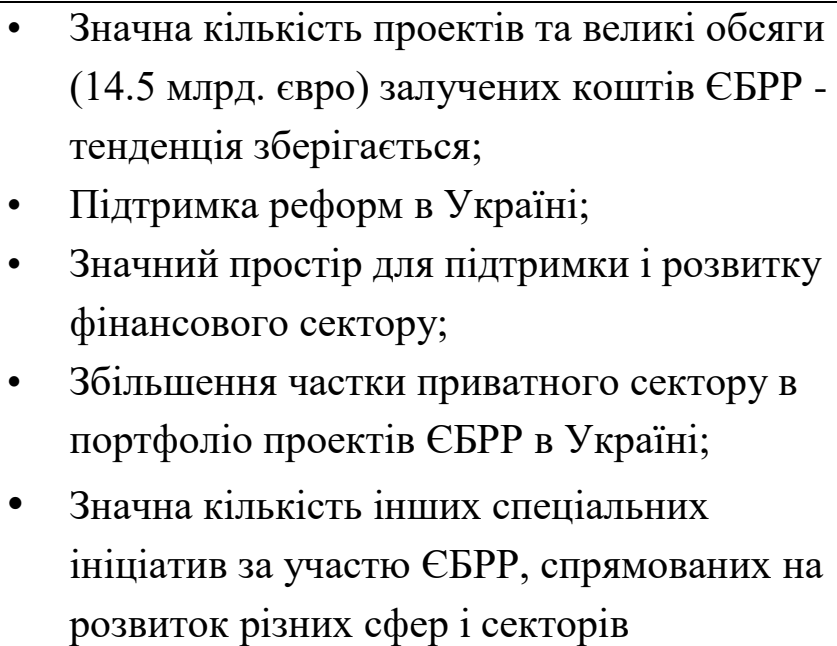 & $\begin{array}{l}\text { • } \\
\text { Тривалі терміни затвердження кредиту } \\
\text { Банком; } \\
\text { • Високий рівень бюрократизації під час } \\
\text { подання заявки на одержання коштів } \\
\text { затримує виконання проектів та зменшує } \\
\text { позитивні ефекти; } \\
\text { • Відсутність комплексного моніторингу } \\
\text { ефективності конкретних проектів; } \\
\text { Пандемія Covid-19 }\end{array}$ \\
\hline
\end{tabular}

Проведений аналіз дозволяє сформулювати основні задачі щодо реалізації стратегії співпраці з ЄБРР, спрямовані на розвиток інституційного середовища в Україні та підвищення ефективності функціонування економіки (рис. 4).

\begin{tabular}{|c|c|c|}
\hline & & $\begin{array}{c}\text { Розвиток внутрішнього ринку та експортного } \\
\text { потенціалу новітніх галузей, підтримка компаній із } \\
\text { найкращою практикою }\end{array}$ \\
\hline \multirow{4}{*}{$\begin{array}{c}\text { Основні } \\
\text { задачі щиодо } \\
\text { реалізацї̈ } \\
\text { Стратегії } \\
\text { співпраці } \\
\text { ЕБРР } 3 \\
\text { Украйною }\end{array}$} & \multirow{2}{*}{$\begin{array}{c}\text { Кореляція } \\
\text { зі } \\
\text { стратегією } \\
\text { ЕБРР }\end{array}$} & $\begin{array}{c}\text { Розширення потенціалу співробітництва у } \\
\text { державному секторі } \\
\text { через проекти розвитку інфраструктури та } \\
\text { енергетичної безпеки, комерціалізації компаній, } \\
\text { належного державного управління } \\
\end{array}$ \\
\hline & & $\begin{array}{c}\text { Розширення потенціалу співробітництва з малим і } \\
\text { середнім бізнесом }\end{array}$ \\
\hline & & антикорупційниі реформи та інтеграцію з СС \\
\hline & & $\begin{array}{c}\text { Реорганізація фінансового сектору через розвиток } \\
\text { фінансової інфраструктури та впровадження } \\
\text { новітніх продуктів }\end{array}$ \\
\hline & & $\begin{array}{c}\text { Покращення інвестиційного клімату через } \\
\text { прискорення інституційних реформ, проведення } \\
\text { структурних реформ, розвиток новітніх галузей }\end{array}$ \\
\hline & & $\begin{array}{c}\text { Підготовка управлінських кадрів, підвищення } \\
\text { культури відповідальності }\end{array}$ \\
\hline
\end{tabular}

Puc. 4. Основні задачі щзодо реалізації Стратегї СБРР в Україні для стабілізації економічного розвитку

Джерело: складено авторами. 
Висновки. Отже, СБРР відіграє важливу роль у розвитку економік країн співпраці. Для України ЄБРР є найбільшим інституційним інвестором, проекти якого спрямовані на створення відповідного інституційного середовища, що забезпечує підвищення конкурентоспроможності економіки в цілому та конкретних іiі секторів, реалізацію принципів сталості (енергозбереження, ефективне управління, інклюзивність, кваліфіковані кадри).

За допомогою побудови кореляційної матриці, регресійних рівнянь та проведення каузального тесту Грейнджера, було доведено, що інвестиції СБРР в Україну здійснюють найбільший вплив на такі показники: ВВП на душу населення, кінцеву енергоємність валового внутрішнього продукту, валову додану вартість, індекс сприйняття корупції; рейтинг Doing Business. Середній вплив інвестицій ЄБРР виявлено на ВВП на душу населення в Україні, місце в індексі глобальної конкурентоспроможності та сприйняття корупції. Всі ці показники характеризують напрямки трансформації української економічної системи. Тобто діяльність ЄБРР спрямована головним чином на формування, розвиток та мультикативний вплив механізмів, які будуть сприяти системним трансформаціям. Конкретні проекти виконують роль інструмента.

Стратегічні пріоритети, визначені до 2023 р., розширюють сфери співпраці, зважаючи на зовнішні виклики, пов'язані із Covid-19. Але переважна частина напрямків є вже апробована і потребує поглиблення. До пріоритетних напрямків відносять наступні: комерціалізація в державному секторі, ефективне управління, підтримка МСП, формування рівних умов конкуренції в приватному секторі, боротьба з корупцією, енергетична безпека, просування поновлюваних джерел енергії, стійкість фінансової системи, посилення інтеграції, зближення зі стандартами ЄС. Це ставить низку завдань перед Україною.

Перспективами реалізації стратегії $\epsilon$ підвищення інвестиційної привабливості України, зменшення рівня корупції, підняття в рейтингу легкості ведення бізнесу, побудова ефективного фінансового ринку i, як наслідок, залучення більших обсягів інвестицій як з боку СБРР, так і інших інвесторів та міжнародних фінансових організацій для забезпечення стійкого розвитку економіки України.

\section{Лimepamypa:}

1. Іванов С. М., Клименко К. В. Співробітництво України та ЄБРР: тенденції розвитку [Електронний ресурс] // Міжнародні фінанси. Наукові праці НДФІ. - 2016. - №3(76). - С.5-23. Режим доступу: http://npndfi.org.ua/docs/NP_16_03_005_uk.pdf; Швець, Г. О. Співробітництво ЄБРР та України у сфері малого та середнього підприємництва / Г. О. Швець // Теоретичні і практичні аспекти економіки та інтелектуальної власності $=$ Theoretical and Practical Aspects of Economics and Intellectual Property : зб. наук. праць / ДВНЗ «ПДТУ». - Маріуполь, 2018. - Вип. 18. - С. 99-105. Режим доступу: http://eir.pstu.edu/bitstream/handle/123456789/23501/15.pdf? 
sequence=1; Хімій Б.І. Європейський банк реконструкції та розвитку: співпраця з Україною // Економіка. Інвестиційні процеси. Бізнесінформ. - 2019. - №10. - С.64-69. - Режим доступу: https://www.business-inform.net/export_pdf/business-inform-2019-10_0-pages-64_69.pdf;

2. Смагло О.В. Стан та перспективи розвитку співпраці між Україною та міжнародними інституціями [Електронний ресурс] // Економіка і суспільство. - 2018. - Вип.14. -С.856-861. Режим доступу: https://economyandsociety.in.ua/journals/14_ukr/123.pdf ; Миськів Г. Кредити міжнародних фінансових організацій в економіці України // Фінансовий простір. - 2015. - № 2(18). - C. 48-58. - Режим доступу: http://www.irbis-nbuv.gov.ua/cgi-bin/irbis_nbuv/cgiirbis_ 64.exe?I21DBN=LINK\&P21DBN=UJRN\&Z21ID $=\& S 21 \mathrm{REF}=10 \& S 21 \mathrm{CNR}=20 \& S 21 \mathrm{STN}=1 \& \mathrm{~S} 21 \mathrm{~F}$ $\mathrm{MT}=\mathrm{ASP} \_m e t a \& C 21 \mathrm{COM}=\mathrm{S} \& 2 \_S 21 \mathrm{P} 03=F I L A=\& 2 \_S 21 \mathrm{STR}=F i n \_p r \_2015 \_2 \_7$

3. Hagiu, Alina; Bărbulescu, Marinela; Voicu, Denisa Maria. The role of European Bank for Reconstruction and Development in financing Romania's economy before and during COVID-19 pandemic [Електронний ресурс] // Agricultural Management / Lucrari Stiintifice Seria I, Management Agricol . 2020, Vol. 22 Issue 2, p253-260. - Режим доступу: http://sma.ro/index.php/lsma/article/view/1779

4. Kosutic A. EBRD investments in the financial sector of the Serbia [Електронний ресурс] // Proceedings of FIKUSZ Symposium for Young Researchers; Budapest: Óbuda University Keleti Károly Faculty of Economics. - 2018. - P.248-270. - Режим доступу: http://kgk.uniobuda.hu/sites/default/files/FIKUSZ_2018_Proceedings.pdf

5. Kryg N. What determines non-financial project success? Evidence from the EBRD [Електронний ресурс] // EBRD Working Paper - 2018. - No. 210. - 26 р. - Режим доступу: https://papers.ssrn.com/sol3/papers.cfm?abstract_id=3155312

6. Рейтинг зростання пострадянських економік [Електронний ресурс] // Forbes Україна Режим доступу: https://minfin.com.ua/2015/02/19/6243708/

7. Іскакова Г. Політичні процеси на пострадянському просторі: тенденції, протиріччя, перспективи [Електронний ресурс] // Політичний менеджмент: трансформаційні процеси 2017. - № 3. - С. 128-134. Режим доступу: http://nbuv.gov.ua/UJRN/PoMe_2007_3_15

8. EBRD. Regions. Eastern Europe and the Caucasus [Електронний ресурс] ] - Режим доступу до ресурсу: https://www.ebrd.com/where-we-are.html

9. Міністерство фінансів України. Європейський банк реконмтрукції та розвитку. [Електронний ресурс] - Режим доступу: https://mof.gov.ua/uk/ebrr

10. EBRD. The EBRD in Ukrain [Електронний ресурс] // European Bank for Reconstruction and Development - Режим доступу: https://www.ebrd.com/ukraine.html

11. EBRD Financial Report 2020 [Електронний ресурс] // European Bank for Reconstruction and Development - Режим доступу: https://www.ebrd.com/news/publications/financialreport/financial-report-2020.html

12. EBRD. Ukrain data. [Електронний ресурс] // European Bank for Reconstruction and Development. - Режим доступу: https://www.ebrd.com/where-we-are/ukraine/data.html

13. EBRD. Chernobyl: a site transformed [Електронний ресурс] // European Bank for Reconstruction and Development. - Режим доступу: https://www.ebrd.com/what-wedo/sectors/nuclear-safety/chernobyl-overview.html

14. EBRD. Ukraine overview [Електронний ресурс] // European Bank for Reconstruction and Development. - Режим доступу: https://www.ebrd.com/where-we-are/ukraine/overview.html

15. Фролов С. М. Дослідження причинно-наслідкових зв'язків складових зовнішньоторговельного обороту й економічних показників регіону, країни та світу [Електронний ресурс] // Проблеми економіки. - 2016. - №1. - С.282-288. - Режим доступу: https://www.problecon.com/export_pdf/problems-of-economy-2016-1_0-pages-282_288.pdf 
16. Ukrainian Country Strategy, 2018-2023. [Електронний ресурс] // European Bank for Reconstruction and Development. - 2018. - Режим доступу: https://www.ebrd.com/where-weare/ukraine/overview.html

\section{References:}

1. Ivanov S.M., Klymenko K.V. (2016) Spivrobitnytstvo Ukrainy ta YeBRR: tendentsii rozvytku [Cooperation between Ukraine and the EBRD: development trends] Mizhnarodni finansy. Naukovi pratsi NDFI - International finance. Scientific works of NDFI, №3(76), 5-23. Retrieved from http://npndfi.org.ua/docs/NP_16_03_005_uk.pdf; Shvets, H.O. (2018) Spivrobitnytstvo YeBRR ta Ukrainy u sferi maloho ta serednoho pidpryiemnytstva [Cooperation between the EBRD and Ukraine in the field of small and medium enterprises] Teoretychni $i$ praktychni aspekty ekonomiky ta intelektualnoi vlasnosti : zbirnyr naukovyh prats / DVNZ «PDTU». Mariupol, - Theoretical and practical aspects of economics and intellectual property: Coll. Science. works / SHEI "PDTU". Mariupol, 18, 99-105. Retrieved from http://eir.pstu.edu/bitstream/handle/123456789/23501/15.pdf? sequence $=1$; Khimii B.I. (2019) Yevropeiskyi bank rekonstruktsii ta rozvytku: spivpratsia z Ukrainoiu [European Bank for Reconstruction and Development: cooperation with Ukraine] Ekonomika. Investytsiini protsesy. Biznesinform - Economy. Investment processes. Businessinform, 10, 64-69. Retrieved from https://www.business-inform.net/export_pdf/business-inform-2019-10_0-pages64_69.pdf [in Ukrainian]

2. Smahlo O.V. (2018) Stan ta perspektyvy rozvytku spivpratsi mizh Ukrainoiu ta mizhnarodnymy instytutsiiamy [Status and prospects of cooperation between Ukraine and international institutions] Ekonomika $i$ suspilstvo - Economy and Society 14, 856-861. Retrieved from https://economyandsociety.in.ua/journals/14_ukr/123.pdf; Myskiv H. (2015) Kredyty mizhnarodnykh finansovykh orhanizatsii $\mathrm{v}$ ekonomitsi Ukrainy [Loans of international financial organizations in the economy of Ukraine] Finansovyi prostir - Financial space 2(18), 48-58. Retrieved from http://www.irbisnbuv.gov.ua/cgibin/irbis_nbuv/cgiirbis_64.exe?I21DBN=LINK\&P21DBN=UJRN\&Z21ID=\&S21REF=10 $\& S 21 C N R=20 \& S 21 S T N=1 \& S 21 F M T=A S P \_m e t a \& C 21 C O M=S \& 2 \_S 21 P 03=F I L A=\& 2 \_S 21 S T R=F i n \_p r$ _2015_2_7 [in Ukrainian]

3. Hagiu, Alina; Bărbulescu, Marinela; Voicu, Denisa Maria (2020) The role of European Bank for Reconstruction and Development in financing Romania's economy before and during COVID-19 pandemic. Agricultural Management / Lucrari Stiintifice Seria I, Management Agricol, Vol. 22, Issue 2, 253-260. Retrieved from http://lsma.ro/index.php/lsma/article/view/1779 [in English]

4. Kosutic A. (2018) EBRD investments in the financial sector of the Serbia. Proceedings of FIKUSZ Symposium for Young Researchers; Budapest Óbuda University Keleti Károly Faculty of Economics. 248-270. Retrieved from http://kgk.uni-obuda.hu/sites/default/files/FIKUSZ_2018_ Proceedings.pdf [in English]

5. Kryg N. (2018) What determines non-financial project success? Evidence from the EBRD. EBRD Working Paper, No. 210. Retrieved from https://papers.ssrn.com/sol3/papers.cfm?abstract_ id=3155312 [in English]

6. Reitynh zrostannia postradianskykh ekonomik [Growth rating of post-Soviet economies] Forbes Ukraina - Forbes Ukraine. Retrieved from https://minfin.com.ua/2015/02/19/6243708/ [in Ukrainian]

7. Iskakova H. (2017) Politychni protsesy na postradianskomu prostori: tendentsii, protyrichchia, perspektyvy [Political processes in the post-Soviet space: trends, contradictions, prospects] Politychnyi menedzhment: transformatsiini protsesy - Political management: transformational processes, 3. 128-134. Retrieved from http://nbuv.gov.ua/UJRN/PoMe_2007_3_15 [in Ukrainian] 
8. EBRD. Regions. Eastern Europe and the Caucasus. Retrieved from https://www.ebrd.com/where-we-are.html [in English]

9. Ministerstvo finansiv Ukrainy. Yevropeiskyi bank rekonmtruktsii ta rozvytku [Ministry of Finance of Ukraine. European Bank for Reconstruction and Development] Retrieved from https://mof.gov.ua/uk/ebrr [in Ukrainian]

10. EBRD. The EBRD in Ukrain. European Bank for Reconstruction and Development Retrieved from https://www.ebrd.com/ukraine.html [in English]

11. EBRD Financial Report 2020. European Bank for Reconstruction and Development. Retrieved from https://www.ebrd.com/news/publications/financial-report/financial-report-2020.html [in English]

12. EBRD. Ukrain data. European Bank for Reconstruction and Development. Retrieved from https://www.ebrd.com/where-we-are/ukraine/data.html [in English]

13. EBRD. Chernobyl: a site transformed. European Bank for Reconstruction and Development. Retrieved from https://www.ebrd.com/what-we-do/sectors/nuclear-safety/chernobyl-overview.html [in English]

14. EBRD. Ukraine overview. European Bank for Reconstruction and Development. Retrieved from https://www.ebrd.com/where-we-are/ukraine/overview.html [in English]

15. Frolov S.M. (2016) Doslidzhennia prychynno-naslidkovykh zviazkiv skladovykh zovnishnotorhovelnoho oborotu y ekonomichnykh pokaznykiv rehionu, krainy ta svitu [Research of causal relations of components of foreign trade turnover and economic indicators of region, country and world] Problemy ekonomiky - Problems of economy, 1, 282-288. Retrieved from https://www.problecon.com/export_pdf/problems-of-economy-2016-1_0-pages-282_288.pdf [in Ukrainian]

16. Ukrainian Country Strategy, 2018-2023. European Bank for Reconstruction and Development. Retrieved from https://www.ebrd.com/where-we-are/ukraine/overview.html [in English] 